\title{
West Nile virus in Europe: understanding the present to gauge the future
}

P Reiter (paul.reiter@pasteur.fr) ${ }^{1}$

1. Insects and Infectious Disease Unit, Institut Pasteur, Paris, France

Citation style for this article:

Citation style for this article: Reiter P. West Nile virus in Europe: understanding the present to gauge the future. Euro Surveill. 2010;15(10):pii=19508. Available online: http://www.eurosurveillance.org/ViewArticle.aspx?Articleld=19508

The appearance of West Nile virus in New York in 1999 and the unprecedented panzootic that followed, have stimulated a major research effort in the western hemisphere and a new interest in the presence of this virus in the Old World. This review considers current understanding of the natural history of this pathogen, with particular regard to transmission in Europe.

\section{Background}

West Nile virus (WNV) is by far the most widely distributed arbovirus. It belongs to the Japanese encephalitis antigenic complex of the family Flaviviridae, transmitted in an avian cycle by ornithophilic mosquitoes, chiefly of the genus Culex [1]. Mammals can also be infected, but are considered dead end hosts because viraemia is generally too low to infect mosquitoes [2].

Mosquitoes acquire infection by feeding on a viraemic host. Virus passes through the gut wall into the haemolymph, the 'blood' of the insect, after which replication occurs in most of the internal tissues. When the salivary glands are infected, the virus can pass to a new host via saliva injected into the skin by the insect when it takes a blood meal. The period from the infective blood meal to infectivity, the extrinsic incubation period, lasts 10-14 days depending on temperature. Ornithophilic vectors that also bite and infect mammals, including humans, are termed bridge vectors.

Human infections attributable to WNV have been reported in many countries in the Old World for more than 50 years [3-5]. In recent years these have included Algeria 1994 (eight deaths) [6], Romania 1996-2000 (21 deaths) [7], Tunisia 1997 (eight deaths) [8], Russia 1999 (40 deaths) [9], Israel 2000 (42 deaths) [10], and Sudan 2004 (four deaths) [11]. By far the largest outbreaks occurred in Bucharest in 1996 (393 hospitalised cases, 17 deaths) and Volgograd in 1999 (826 hospitalised cases, 40 deaths). Both occurred in urban areas and were associated with cellars flooded with sewagepolluted water in poorly maintained apartment blocks, a highly productive breeding site for an effective vector, Culex pipiens $[7,9,12]$. Outbreaks on this scale have also occurred in Israel [13]. All three sites are on major migratory routes of birds that overwinter in Africa.
In its original range, WNV is enzootic throughout Africa, parts of Europe, Asia and Australia, but it received little attention until 1999, when a topotype circulating in Tunisia and Israel appeared in the Bronx, New York $[14,15]$, probably imported in a live bird. The epizootic that followed was spectacular and unprecedented: within five years, the virus appeared ubiquitous, sometimes common, in nearly all counties of every state east of the Rocky Mountains, as well as parts of western Nevada and southern California. Sizeable outbreaks were also observed in six Canadian provinces. It is now widely established from Canada to Venezuela. To date (1999-2009), 29,606 clinical cases and 1,423 deaths have been reported in humans, and more than 27,000 cases in horses, with a case fatality rate of about $33 \%$ [16]. Two thirds of the horse population in the United States are now vaccinated, but no vaccine is available for humans.

\section{The virus}

Two lineages of WNV are widely recognised that are about $30 \%$ divergent [14]. Lineage I includes WNV strains from Africa, the Middle East, Europe, India, Australia (formerly Kunjin virus) and the Americas. The close relationship between isolates from Kenya, Romania and Senegal are evidence of the geographic mobility of the virus in migratory birds [17]. The virus isolated in the Bronx, New York in 1999 was closely related to Lineage I strains circulating in Israel and Tunisia a year earlier [18] and most probably imported in a wild bird. Until recently, all isolates of Lineage II were from Sub-Saharan Africa and Madagascar, but in 2004, it was isolated from a goshawk in Hungary, and from several birds of prey in 2005 [19].

At least five new lineages have been proposed for strains isolated in central Europe, Russia and India [2023]. This is not surprising, given that the original range of the virus spans Europe, Africa, Asia and Australia, the increasing accessibility of sequencing technology, and the enormous interest in the virus since its appearance in North America. Lastly, a new genotype was identified in the US in 2003 and may now be the dominant strain in North America [24,25]. 


\section{Pathology}

Only a small portion of human infections are symptomatic, with the headache, tiredness, body aches and swollen lymph glands typical of many febrile diseases. Occasionally there is an abdominal rash. About one in 150 patients develop one or multiple indicators of neuro-invasive disease; neck stiffness, stupor, disorientation, coma, tremors, convulsions, muscle weakness, and paralysis. This can occur in people of any age, but those over 50 years are at highest risk [26]. In the past five years, $4.8 \%$ of laboratory-confirmed clinical infections reported in the US were fatal. Symptomatic infections in horses are also rare and generally mild, but can cause neurologic disease including fatal encephalomyelitis [27].

In the Old World, mortality in birds associated with WNV infection is rare [28], although significant numbers of storks and domestic geese died during epizootics in Israel [29]. In striking contrast, the virus is highly pathogenic for New World birds; the appearance of large numbers of dead or dying birds is often an indicator of local transmission [30]. In the early days following appearance of the virus in the US, it appeared that members of the crow family (Corvidae) were particularly susceptible, but virus has been detected in dead and dying birds of more than 250 species - with viraemia as high as $109 \mathrm{pfu} / \mathrm{ml}$ - as well as various species of mammals and even in alligators [1]. In rural Europe, in the absence of large-scale bird mortality, neurologic symptoms in horses are often the sole indication of local presence of the virus.

\section{Vectors}

Mosquitoes of the genus Culex are generally considered the principal vectors of WNV, both in the Old World and in the Americas. Studies with bird-baited traps in the wetlands of Mediterranean Europe indicate four such species are dominant. For example, in a region of the Danube delta that has enormous populations of resident and migrant birds, $82 \%$ of mosquito captures in 2008 ( $>10,000$ mosquitoes, 17 species) were of three species: Cx. pipiens (44\%), Cx. torrentium (27\%) and $C x$. modestus (11\%). Coquillettidia richardii (14\%) and Anopheles maculipennis (3\%) made up all but $1 \%$ of the remaining species (F-L Prioteasa, personal communication). In contrast, $C X$. modestus and $C$. richardii were the dominant species captured on humans in the same area (35\% and $34 \%$, respectively), while Cx. pipiens was one of five species that contributed less than $2 \%$ of the catch. On the other hand, $93 \%$ of all mosquitoes captured by bird-baited traps in a village were $C x$. pipiens, $5 \%$ were $C x$. torrentium, and neither $C x$. modestus nor $C$. richardii were present. Similarly, in many urban areas, $C x$. pipiens is the dominant species, and bloodmeal analysis confirms that it is highly ornithophilic [31]. These data illustrate the complex relationship between abundance, species composition, host preference and vector competence. It has been suggested that a decline in bird populations in the autumn migration season augments the incidence of mammal-biting, but this is not borne out by field studies in Chicago, Illinois, an area of intense transmission [32].

In a study in the Danube delta study WNV was indicated by RAMP kit (Response BiomedicaL Corporation, Canada; a commercial kit based on WNV-specific antibodies with high specificity and sensitivity, [33,34]) in 14 pools of mosquitoes: 11 of $C x$. pipiens, two of $C x$. torrentium and one of An. maculipennis (F-L Prioteasa, personal communication). In a laboratory study of mosquitoes from the Rhone delta, France, infection and transmission rates were $89.2 \%$ and $54.5 \%$, respectively, for $C x$. modestus, and $38.5 \%$ and $15.8 \%$, respectively, for $C x$. pipiens $[35,36]$. Coupled with this high potential as a vector, $C x$. modestus is abundant in reed-beds that are very probably an important ecotope for WNV transmission.

In New York following the appearance of the virus in the US, WNV RNA was detected in three pools of overwintering $C x$. pipiens, and virus was isolated from one of these [37]. In the Czech Republic, virus was detected in overwintering $C x$. pipiens by PCR, but not confirmed by isolation (Z Hubalek and Iwo Rolf, personal communication), and in the Danube delta region, four pools of $C x$. pipiens and one of An. maculipennis tested positive by RAMP (F-L Prioteasa, personal communication). These results, although not confirmed by virus isolation, are particularly interesting because a field study of Culex species in Massachusetts, US, confirmed that females do not feed on blood before overwintering (P. Reiter, unpublished data). This implies that these insects acquire their infection by vertical transmission between generations via the egg stage. Moreover, in the spring of the year of the study, a few days after mosquitoes had exited their overwintering sites, a number of WNV-positive crows were collected in a neighbouring states, circumstantial evidence that infected overwintering females had transmitted virus to these birds in their first (post-winter) blood meal. Lastly, WNV has been isolated from male $C x$. pipiens in Connecticut, US, further evidence of vertical transmission [38], and from larvae of $C x$. univittatus s.l. in the Rift Valley, Kenya [39].

\section{Transmission between vertebrates}

In a landmark study, 25 bird species representing 17 families and 10 orders were exposed to WNV by infectious mosquito bite. Only four of 87 individuals did not develop a detectable viraemia [40]. The most competent species, judged by magnitude and duration of viraemia, were passerines (perching birds, 11 species, including members of the crow family) and charadriiformes (a wader and a gull). In surviving birds, the infection persisted in certain organs in 16 of 41 infected birds until euthanised on day 14 after infection. In addition, five of 15 species (representing 11 families) became infected when virus was placed in the back of the oral cavity (either in suspension or as a single infected mosquito) and crows were infected 
when fed a dead infected sparrow. Furthermore, virus was observed in the faeces of 17 of 24 species and in the oral cavity of 12 of 14 species for up to 10 days after infection. Moreover, contact transmission between cage mates was observed in four species. In summary, birds can be infected by a variety of routes other than mosquito bites, and different species may have different potential for maintaining the transmission cycle.

In the light of this complexity, the spectacular conquest of the New World by WNV demands attention. Mosquito-borne transmission involves both the extrinsic and intrinsic incubation periods; even at high ambient temperatures this takes a minimum of 10-14 days, so it is hard to imagine that the virus could have traversed an entire continent in a period of four or five summers by this mechanism alone. Importation by infected migrant birds returning from their overwintering grounds could explain the distribution. Indeed, a new region of transmission, separate from the northern states, did appear in Florida and adjoining states two years after the initial New York infestation, presumably introduced by infected migrant birds, but thereafter the virus progressed rapidly westward along a broad front stretching from Canada to the Gulf of Mexico [41]. By 2003, by far the majority of counties east of the Rocky Mountains had reported confirmed WNV-positive dying birds.

An alternative explanation for dispersal rests on oral infection: crows are scavengers and feed on carrion, including dead crows. They are social birds, roost in large crowded colonies, have a wide daily dispersal range of up to $20 \mathrm{~km}$ in all directions, and their feeding grounds overlap with crows from other roosts. They also exhibit "kin-based cooperative breeding" in which grown offspring remain with their parents to rear new young [42]. It is conceivable that: (i) crows that die away from their roost relay virus by oral infection to birds from neighbouring roosts; (ii) faecal-oral transmission is significant in crowded roosts, (iii) crows feeding on carcasses of other infected species/animals introduce the infection to others in their roosts, and (iv) viraemic adult and juvenile birds infect nestlings per os. In this way, bird-to-bird transmission, particularly among social birds, could be a major, even the principal driver of amplification and dispersal, with mosquito-borne transmission active at the local level. Modelling studies give some support for this hypothesis [43].

There is also good evidence that oral and faecal-oral infection may be important in transmission dynamics in other species. In the New World, mortality in many species of raptors is out of all proportion to their abundance in nature [44-46]. Fatal infections in Imperial Eagles in Spain and goshawks in Hungary [47], high seroprevalence in kestrels in Egypt [48], and high mortality in flocks of domestic geese in Israel [49] and Hungary [47] point to the same mechanism.
Oral infection is not limited to consumption of dead or dying birds. For example, adult hamsters are readily infected by ingestion of infected material as well as by mosquito bite [50]. In these animals, virus is rapidly cleared from the blood, but can survive in the central nervous system for at least 86 days [51]. Moreover, as a chronic renal infection, virus is excreted in the urine for at least eight months [52]. Thus, even if viraemia in mammals is insufficient to infect mosquitoes, it may still contribute to infection of scavengers and raptors. Circumstantial evidence for this may be the high mortality of owls, which largely feed on nocturnal rodents and other small mammals. For example, an epizootic of 64 dead or dying Great Horned Owls received by a wildlife rehabitation centre in Ohio in the space of six weeks was attributed to WNV [53], and there are similar reports from other sites in the US. Lastly, large dieoff in an alligator farm in Georgia has been attributed to the alligators' diet of horse meat [54].

In the 1950 s, up to $100 \%$ of hooded crows (Corvus corone sardonius) and more than $80 \%$ of the human population sampled in a group of villages at the southern end of the Nile delta, $50 \mathrm{~km}$ north of Cairo, Egypt, were seropositive for WNV, and more than $80 \%$ of the human population were also seropositive [55]. Laboratory studies confirmed that the birds were highly susceptible to WNV infection with consistently high titres of viraemia. The African species is not markedly social in habits, but it may be that, as in the New World, carrion feeding contributes to the high infection rate, and it is tempting to speculate that the virus is particularly adapted to corvids and raptors. Moreover, these birds feed by tearing shreds of meat from carrion or prey and packing them into a large storage bolus in the crop, after which fragments of the bolus are moved, piece by piece, to the stomach. Virus will be destroyed by the low $\mathrm{pH}$ of the stomach, but presumably until then, infection can occur by contact with the walls of the crop.

The contrast in pathogenicity between the Old and the New World is indicative of a long association between the virus and its avian hosts in its original range. Indeed, bird species with low mortality in the Americas are those that, like the virus, are exotics imported from the Old World. In this context, there is a clear parallel with another Old World flavivirus, yellow fever virus, which was transported to the Americas from Africa in the slave trade. In its original range, infections in wild primates, the enzootic hosts, are asymptomatic, but in the Americas, the virus is lethal to monkeys; local inhabitants recognise an epizootic when the rain forest goes 'silent' because of mass mortality among Howler monkeys. In both cases, the introduction of an exotic zoonotic virus that is not pathogenic in its original range (presumably because it has a long history of contact with its hosts) has had a catastrophic impact on the local fauna in its new habitat. This is an important point: it is probably inappropriate to suggest that WNV will emerge as a serious pathogen in the Old 
World on the basis of what has happened in the past decade in the Americas.

\section{Bird migration}

In a serosurvey along the entire Nile valley, from southern Sudan to the Nile delta, seropositive humans were present at 39 of 40 locations [48]. The river is one of the world's major routes for migrating birds, and the continuation of this flyway into Europe, via the Levant, the Bosporus and into eastern Europe, is a pathway with a consistent history of equine and human cases of WNV. Indeed, more than 130 records of suspected and confirmed WNV infection, dating back to the 1950s, have recently been collected from archives of health reports in Romania (G. Nicolescu, personal communication). It is interesting, however, that although the seasonal pattern of West Nile fever cases in Egypt and Romania is roughly synchronous, the seroprevalence data suggest a much higher and more consistent rate of transmission south of the Mediterranean. Moreover, the Nile valley study, there was little indication of significant mortality in humans; WNV appeared to be a childhood infection and the majority of people in older cohorts, who are more vulnerable to central nervous system complications, were already immune.

In a study of 25 species of birds captured in the Guadilquivir delta, southern Spain, trans-Saharan migrant species had higher seroprevalence and higher antibody titres than resident and short-distance migrants, evidence that the migrants are primarily exposed to WNV in areas with higher circulation of virus, rather than in Europe. Indeed, a study in Senegal, where several of these species overwinter, revealed seroprevalence in horses as high as 90\% [56], recalling the high seroprevalence observed along the river Nile [48]. An interesting point regards infections in horses: morbidity and mortality has not been documented in Egypt or Senegal, perhaps an indication of innate immunocompetence in areas of high circulation. The same may to apply to Romania, which has a population of about a million horses but little evidence of symptomatic infections.

\section{Transport of virus}

As already stated, commonality between viral sequences in different geographic areas is clear evidence of transportation in birds. This raises the question: how is it possible that a bird, in which viraemia lasts at most seven our eight days, can carry virus over distances of thousands of kilometres in a flight that lasts many weeks? The simplest explanation is that migrants en route have refuelling stops where they rest and feed before continuing their journey; at these sites, virus could be transmitted between migrants, and to local resident species, so that stopovers become foci of infection. This is plausible at certain sites, for example at desert oases, but transmission in, for example, the Nile valley occurs in mid-summer, after the passage of spring migrants [48]. An alternative explanation is that ectoparasites, such as hippoboscids and ticks, may constitute the real reservoir, carrying the virus on their avian hosts, and somehow transferring it to new birds at the migration destination. Lastly, it has been suggested that migration is stressful, and that this stress may cause a recrudescence of virus in birds with chronic infection. There is no physiological evidence for such stress, and indeed corticosterone levels rise after migration is complete [57]. Moreover, it is unlikely that viraemia in immunocompromised birds would attain levels sufficient to infect mosquitoes. A more likely possibility is that latent virus enters the transmission cycles when migrants are consumed by scavengers or raptors, or when feeding their young.

\section{Vector control}

In the US, ultra-low-volume fogging with adulticidal aerosols of insecticides delivered from road vehicles is widely used to combat WNV vectors and nuisance mosquitoes in residential areas. Unfortunately, the efficacy of this technique is affected by spacing between buildings, distance between roads, amount and type of vegetation, wind, convection and many other factors, and realistic field evaluations have given markedly variable results $[58,59]$. Moreover, aerosols do not affect the aquatic stages of the insects, and mortality of adults is restricted to those that are in flight and exposed in the short time, a matter of minutes, that the aerosol is airborne in lethal concentrations. For this and many other reasons, the epidemiological impact of fogging is hard to assess [6o], and may be minor at best.

In Europe, most transmission is associated with wetland areas of high biodiversity where, apart from difficulty of access, the use of insecticides is undesirable. In urban areas, a logical approach is the elimination of larval habitat. Graded drainage systems and other measures of basic sanitation are key to eliminating the problem at source, but this is not always straightforward. For example, water in catch-basins (settling tanks below street-drains) can be a major source of $C x$. pipiens during dry weather, but they are difficult to treat effectively because they are flushed by rainfall. The problem in poorly constructed apartment buildings, such as occurred in Bucharest, will require major reconstruction.

\section{Weather and WNV recrudescence}

A great deal of attention has been paid to the potential impact of climate change on the prevalence and incidence of mosquito-borne disease [61]. Given that WNV is rarely evident in the Old World, however, it is hard to assess the role of climatic factors in its transmission. In this context it is therefore pertinent to review knowledge about Saint Louis encephalitis virus (SLEV), a closely related counterpart in the New World that has been the subject of research in the Americas since the 1930s, for the similarities to WNV are striking:

- Both are flaviviruses in the Japanese encephalitis complex. 
- Both are transmitted between birds by ornithophilic mosquitoes, mainly of the genus Culex.

- Transmission of SLEV is rarely evident because infections in birds are asymptomatic, as is the case with WNV in the Old World.

- As in Europe, urban epidemics of Saint Louis encephalitis have occurred in areas of poor sanitation, where sewage-polluted ditches and other collections of organically rich water lead to large numbers of Culex mosquitoes.

- Infection of humans and horses can cause encephalitis, sometimes fatal.

- Mammals appear to be dead-end hosts; viraemia is insufficient to infect mosquitoes.

In common with WNV and indeed many other arboviruses, SLEV can remain undetected over long periods of time. It is only at erratic intervals, sometimes separated by several decades, that a sudden recrudescence is observed, occasionally developing into a significant epizootic. For example, the last major outbreak of Saint Louis encephalitis in North America was in 1976, yet despite a massive increase in surveillance of mosquitoes and birds for WNV (with simultaneous testing for SLEV), only a few small outbreaks have been documented in the past 25 years.

Attempts have been made to associate Saint Louis encephalitis outbreaks with specific weather conditions. In regions of the US where $C x$. pipiens and a second species, $C x$. restuans, are the principal vectors, a pattern of mild winters, cold wet springs and hot dry summers has been associated with epizootics and human cases [62]. In the period since the first major epidemics to be recognised (more than 1,000 cases in St. Louis, Missouri, in neighbourhoods with primitive sanitation and extensive sewage-polluted ditches in 1932 and 1933) the pattern holds true for some, but by no means all outbreaks, nor for years with such conditions but no outbreaks. Hot dry summers are liable to result in large accumulations of organically polluted stagnant water, favoured breeding habitat for $C x$. pipiens, but although a number of summers have fitted this description since the appearance of WNV, and despite an enormous increase in vigilance for WNV, evidence of SLEV transmission has been unusually low. Similarly in Europe, the summers of 1996 and 1999 were unusually hot and dry and coincided with outbreaks in Bucharest and Volgograd, but even hotter and drier years have occurred since then without any accompanying transmission. In short, the causes for recrudescence of both viruses remain enigmatic, and it may well be impossible to associate periods of transmission with specific patterns of weather. Indeed, given that the cradle of transmission is almost certainly south of the Sahara, we may need to look to the African continent for clues; transmission in Europe may represent the tip of the iceberg which has its main mass in the tropics.

\section{Future of WNV in Europe}

As already stated, the spectacular panzootic of WNV in the Americas has drawn attention to this virus, and it has been suggested that it is also an emerging pathogen in the Old World. It is important to put this into perspective: even if we include the urban outbreaks in Romania and Russia, less than 200 deaths in humans have been recorded over the past decade, and the number of equine cases is in the same order of magnitude. While it is true that an increasing number of small outbreaks, mainly among horses, have been reported, at least part of this increase was probably due to increased awareness of the virus, and major improvements in surveillance and diagnostic facilities.

One point is clear: the importation and establishment of vector-borne pathogens that have a relatively low profile in their current habitat is a serious danger to Europe and throughout the world. It is a direct result of the revolution of transport technologies and increasing global trade that has taken place in the past three decades. Modern examples include the global circulation of dengue virus serotypes [63], the intercontinental dissemination of Aedes albopictus and other mosquitoes in used tires $[64,65]$, the epidemic of chikungunya virus in Italy [66], and the importation of bluetongue virus and trypanosomiasis into Europe $[67,68]$. Thus, if for example SLEV were to be introduced into the Old World, there is every reason to believe that it would spark a panzootic analogous to that of WNV in the western hemisphere. In short, globalisation is potentially a far greater challenge to public health in Europe than any future changes in climate [69].

\section{Acknowledgements}

I am grateful to Guy Hendrickx and Sarah Randolph for helpful suggestions. This review is based on a literature study conducted as part of the European Centre for Disease Prevention and Control funded V-borne project "Assessment of the magnitude and impact of vector-borne diseases in Europe", tender $n^{\circ}$ 0J/2007/04/13-PROC/2007/003. It was compiled, edited and reviewed according to the required Euro-Surveillance scientific review format using EDEN funding, EU grant GOCE-2003-010284 EDEN. The paper is catalogued by the EDEN Steering Committee as EDENo196 (http:// www.eden-fp6project.net/). The contents of this publication are the responsibility of the authors and do not necessarily reflect the views nor of the European Centre for Disease Prevention and Control, nor of the European Commission.

\section{References}

1. Hayes E, Komar N, Nasci R, Montgomery S, O’Leary D, Campbell G. Epidemiology and transmission dynamics of West Nile virus disease. Emerg Infect Dis. 2005;11(8):1167-73.

2. Dauphin G, Zientara S, Zeller H, Murgue B. West Nile: worldwide current situation in animals and humans. Comp Immunol Microbiol Infect Dis. 2004;27(5):343-55.

3. Bernkopf H, Levine S, Nerson R. Isolation of West Nile virus in Israel. J Infect Dis. 1953;93(3):207-18.

4. Hubalek Z, Halouzka J, Juricova Z. West Nile fever in Czechland. Emerg Infect Dis. 1999;5(4):594-5.

5. Murgue B, Murri S, Triki H, Deubel V, Zeller HG. West Nile in the Mediterranean basin: 1950-2000. Ann N Y Acad Sci. 2001;951:117-26. 
6. Le Guenno B, Bougermouh A, Azzam T, Bouakaz R. West Nile: a deadly virus? The Lancet. 1996;348(9037):1315.

7. Tsai TF, Popovici F, Cernescu C, Campbell GL, Nedelcu NI. West Nile encephalitis epidemic in southeastern Romania. Lancet. 1998;352(9130):767-71.

8. Feki I, Marrakchi C, Ben Hmida M, Belahsen F, Ben Jemaa M, Maaloul I, et al. Epidemic West Nile virus encephalitis in Tunisia. Neuroepidemiology. 2005;24(1-2):1-7.

9. Platonov AE, Shipulin GA, Shipulina OY, Tyutyunnik EN, Frolochkina TI, Lanciotti RS, et al. Outbreak of West Nile virus infection, Volgograd Region, Russia, 1999. Emerg Infect Dis. 2001;7(1):128-32.

10. Green MS, Weinberger M, Ben-Ezer J, Bin H, Mendelson E, Gandacu D, et al. Long-term Death Rates, West Nile virus epidemic, Israel, 2000. Emerg Infect Dis. 2005;11(11):1754-7.

11. Depoortere E, Kavle J, Keus K, Zeller H, Murri S, Legros D. Outbreak of West Nile virus causing severe neurological involvement in children, Nuba Mountains, Sudan, 2002. Trop Med Int Health. 2004;9(6):730-6.

12. Savage H, Ceianu C, Nicolescu G, Karabatsos N, Lanciotti R. Entomologic and avian investigations of an epidemic of West Nile fever in Romania in 1996, with serologic and molecular characterization of a virus isolate from mosquitoes. Am J Trop Med Hyg. 1999;61(4):600-11. Erratum. Am J Trop Med Hyg. 2000;62(1):162.

13. Weinberger M, Pitlik SD, Gandacu D, Lang R, Nassar F, Ben David D, et al. West Nile fever outbreak, Israel, 2000: epidemiologic aspects. Emerg Infect Dis. 2001;7(4):686-91.

14. Lanciotti RS, Roehrig JT, Deubel V, Smith J, Parker M, Steele K, et al. Origin of the West Nile virus responsible for an outbreak of encephalitis in the northeastern United States. Science. 1999;286(5448):2333-7.

15. Hayes CG. West Nile virus: Uganda, 1937, to New York City, 1999. Ann N Y Acad Sci. 2001;951:25-37.

16. Centers for Disease Control and Prevention; December 2009, available from http://www.cdc.gov/ncidod/dvbid/westnile/ surv\&controlCaseCountog detailed.htm.

17. Charrel RN, Brault AC, Gallian P, Lemasson J), Murgue B, Murri $S$, et al. Evolutionary relationship between Old World West Nile virus strains. Evidence for viral gene flow between Africa, the Middle East, and Europe. Virology. 2003;315(2):381-8.

18. Lanciotti R, Ebel G, Deubel V, Kerst A, Murri S. Complete genome sequences and phylogenetic analysis ofWest Nile virus strains isolated from the United States, Europe, and the Middle East. Virology. 2002;298(1):96-105.

19. Erdelyi K, Ursu K, Ferenczi E, Szeredi L, Ratz F, Skare J, et al. Clinical and pathologic features of lineage 2 West Nile virus infections in birds of prey in Hungary. Vector Borne Zoonotic Dis. 2007 Summer;7(2):181-8.

20. Bakonyi T, Hubalek Z, Rudolf I, Nowotny N. Novel flavivirus or new lineage of West Nile virus, central Europe. Emerg Infect Dis. 2005;11(2):225-31.

21. Lvov D, Butenko A, Gromashevsky V, Kovtunov A, Prilipov A, Kinney R, et al. West Nile virus and other zoonotic viruses in Russia: examples of emerging reemerging situations. Arch Virol Suppl. 2004;(18):85-96.

22. Bondre VP, Jadi RS, Mishra AC, Yergolkar PN, Arankalle VA. West Nile virus isolates from India: evidence for a distinct genetic lineage. J Gen Virol. 2007;88(Pt 3):875-84.

23. Kramer LD, Styer LM, Ebel GD. A global perspective on the epidemiology of West Nile virus. Annu Rev Entomol. 2008;53:61-81.

24. Davis C, Ebel G, Lanciotti R, Brault A, Guzman H. Phylogenetic analysis of North American West Nile virus isolates, 20012004: evidence for the emergence of a dominant genotype. Virology. 2005;342(2):252-65.

25. Snapinn KW, Holmes EC, Young DS, Bernard KA, Kramer LD, Ebel GD. Declining growth rate of West Nile virus in North America. J Virol. 2007;81(5):2531-4.

26. Hayes EB, Sejvar JJ, Zaki SR, Lanciotti RS, Bode AV, Campbell GL. Virology, pathology, and clinical manifestations of West Nile virus disease. Emerg Infect Dis. 2005;11(8):1174-9.

27. Cantile C, Di Guardo G, Eleni C, Arispici M. Clinical and neuropathological features of West Nile virus equine encephalomyelitis in Italy. Equine Vet J. 2000;32(1):31-5.

28. Hubalek Z, Halouzka J. West Nile fever--a reemerging mosquito-borne viral disease in Europe. Emerg Infect Dis. 1999;5(5):643-50.

29. Malkinson M, Banet C, Weisman Y, Pokamunski S, King $\mathrm{R}$, Drouet MT, et al. Introduction of West Nile virus in the Middle East by migrating white storks. Emerg Infect Dis. 2002;8(4):392-7.
30. Steele KE, Linn MJ, Schoepp RJ, Komar N, Geisbert TW, Manduca RM, et al. Pathology of fatal West Nile virus infections in native and exotic birds during the 1999 outbreak in New York City, New York. Vet Pathol. 2000;37(3):208-24.

31. Hamer GL, Kitron UD, Brawn JD, Loss SR, Ruiz MO, Goldberg TL, et al. Culex pipiens (Diptera: Culicidae): a bridge vector of West Nile virus to humans. J Med Entomol. 2008;45(1):125-8.

32. Loss SR, Hamer GL, Walker ED, Ruiz MO, Goldberg TL, Kitron UD, et al. Avian host community structure and prevalence of West Nile virus in Chicago, Illinois. Oecologia. 2009;159(2):415-24.

33. Burkhalter KL, Lindsay R, Anderson R, Dibernardo A, Fong W, Nasci RS. Evaluation of commercial assays for detecting West Nile virus antigen. J Am Mosq Control Assoc. 2006;22(1):64-9.

34. Stone WB, Therrien JE, Benson R, Kramer L, Kauffman EB, Eldson $M$, et al. Assays to detect West Nile virus in dead birds. Emerg Infect Dis. 2005;11(11):1770-3.

35. Balenghien T, Vazeille M, Grandadam M, Schaffner F, Zeller H, Reiter P, et al. Vector competence of some French Culex and Aedes mosquitoes for West Nile virus. Vector Borne Zoonotic Dis. 2008;8(5):589-95.

36. Balenghien T, Vazeille M, Reiter $\mathrm{P}$, Schaffner F, Zeller $\mathrm{H}$, Bicout DJ. Evidence of laboratory vector competence of Culex modestus for West Nile virus. J Am Mosq Control Assoc. 2007;23(2):233-6.

37. Nasci RS, Savage HM, White DJ, Miller JR, Cropp BC, Godsey MS, et al. West Nile virus in overwintering Culex mosquitoes, New York City, 2000. Emerg Infect Dis. 2001;7(4):742-4.

38. Anderson JF, Andreadis TG, Main AJ, Ferrandino FJ, Vossbrinck CR. West Nile virus from female and male mosquitoes (Diptera: Culicidae) in subterranean, ground, and canopy habitats in Connecticut. J Med Entomol. 2006;43(5):1010-9.

39. Miller BM, Nasci RS, Godsey MS, Savage HM, Lutwama JJ, Lanciotti RS, et al. First field evidence for natural vertical transmission of West Nile virus in Culex univittatus complex mosquitoes from Rift Valley Province, Kenya. Am J Trop Med Hyg. 2000;62(2):240-6.

40. Komar N, Langevin S, Hinten S, Nemeth N, Edwards E, Hettler $D$, et al. Experimental infection of North American birds with the New York 1999 Strain of West Nile virus. Emerg Infect Dis. 2003;9(3):311-22.

41. Rappole JH, Hubalek Z. Migratory birds and West Nile virus. J Appl Microbiol. 2003;94 Suppl:47S-58S.

42. Baglione V, Canestrari D, Marcos JM, Griesser M, Ekman J. History, environment and social behaviour: experimentally induced cooperative breeding in the carrion crow. Proc Biol Sci. 2002;269(1497):1247-51.

43. Hartemink NA, Davis SA, Reiter P, Hubalek Z, Heesterbeek JA. Importance of bird-to-bird transmission for the establishment of West Nile virus. Vector Borne Zoonotic Dis. 2007 Winter;7(4):575-84.

44. Nemeth NM, Kratz GE, Bates R, Scherpelz JA, Bowen RA, Komar N. Naturally induced humoral immunity to West Nile virus infection in raptors. Ecohealth. 2008;5(3):298-304.

45. Nemeth N, Kratz G, Edwards E, Scherpelz J, Bowen R, Komar N. Surveillance for West Nile virus in clinic-admitted raptors, Colorado. Emerg Infect Dis. 2007 Feb;13(2):305-7.

46. Joyner PH, Kelly S, Shreve AA, Snead SE, Sleeman JM, Pettit DA. West Nile virus in raptors from Virginia during 2003: clinical, diagnostic, and epidemiologic findings. J Wildl Dis. 2006;42(2):335-44

47. Glavits R, Ferenczi E, Ivanics E, Bakonyi T, Mato T, Zarka P, et al. Co-occurrence of West Nile Fever and circovirus infection in a goose flock in Hungary. Avian Pathol. 2005;34(5):408-14.

48. Taylor RM, Work TH, Hurlbut HS, Rizk F. A study of the ecology of west nile virus in Egypt. American Journal of Tropical Medicine and Hygiene. 1956;5:579-620.

49. Banet-Noach C, Simanov L, Malkinson M. Direct (non-vector) transmission of West Nile virus in geese. Avian Pathol. 2003;32(5):489-94.

50. Sbrana E, Tonry JH, Xiao SY, da Rosa AP, Higgs S, Tesh RB. Oral transmission of West Nile virus in a hamster model. Am J Trop Med Hyg. 2005;72(3):325-9.

51. Siddharthan V, Wang H, Motter NE, Hall JO, Skinner RD, Skirpstunas RT, et al. Persistent West Nile virus associated with a neurological sequela in hamsters identified by motor unit number estimation. J Virol. 2009;83(9):4251-61.

52. Tesh RB, Siirin M, Guzman H, Travassos da Rosa AP, Wu X, Duan T, et al. Persistent West Nile virus infection in the golden hamster: studies on its mechanism and possible implications for other flavivirus infections. J Infect Dis. 2005;192(2):287-95.

53. Castalia, Ohio; October 2002, available from http:// backtothewild.com/birdofpreyproblem.html 
54. Miller DL, Mauel MJ, Baldwin C, Burtle G, Ingram D, Hines ME, et al. West Nile virus in farmed alligators. Emerg Infect Dis. 2003;9(7):794-9.

55. Taylor RM, Work TH, Hurlbut HS, Rizk F. A study of the ecology of west nile virus in Egypt. American Journal of Tropical Medicine and Hygiene. 1956;5:579-620.

56. Chevalier V, Lancelot R, Diaite A, Mondet B, Sall B, De Lamballerie X. Serological assessment of West Nile fever virus activity in the pastoral system of Ferlo, Senegal. Ann N Y Acad Sci. 2006;1081:216-25.

57. Reneerkens J, Morrison RI, Ramenofsky M, Piersma T, Wingfield JC. Baseline and stress-induced levels of corticosterone during different life cycle substages in a shorebird on the high arctic breeding grounds. Physiol Biochem Zool. 2002;75(2):200-8.

58. Reiter P, Eliason DA, Francy DB, Moore CG, Campos EG. Apparent influence of the stage of blood meal digestion on the efficacy of ground applied ULV aerosols for the control of urban Culex mosquitoes. I. Field evidence. J Am Mosq Control Assoc. 1990;6(3):366-70.

59. Reddy MR, Spielman A, Lepore TJ, Henley D, Kiszewski AE, Reiter P. Efficacy of resmethrin aerosols applied from the road for suppressing Culex vectors of West Nile virus. Vector Borne Zoonotic Dis. 2006 Summer;6(2):117-27.

6o. Newton EA, Reiter P. A model of the transmission of dengue fever with an evaluation of the impact of ultra-low volume (ULV) insecticide applications on dengue epidemics. Am J Trop Med Hyg. 1992;47(6):709-20.

61. Reiter P. A field trial of expanded polystyrene balls for the control of Culex mosquitoes breeding in pit latrines. J Am Mosq Control Assoc. 1985;1(4):519-21.

62. Reiter P. Weather, vector biology and arboviral recrudescence. Monath TP, editor. Boca Raton, Fl: CRC Press; 1988.

63. Gubler DJ. The global pandemic of dengue/dengue haemorrhagic fever: current status and prospects for the future. Ann Acad Med Singapore. 1998;27(2):227-34.

64. Hawley WA, Reiter P, Copeland RS, Pumpuni CB, Craig GB, Jr. Aedes albopictus in North America: probable introduction in used tires from northern Asia. Science. 1987;29;236(4805):1114-6.

65. Reiter P. Aedes albopictus and the world trade in used tires, 1988-1995: the shape of things to come? J Am Mosq Control Assoc. 1998;14(1):83-94.

66. Angelini R, Finarelli AC, Angelini P, Po C, Petropulacos K, Macini $P$, et al. An outbreak of chikungunya fever in the province of Ravenna, Italy. Euro Surveill. 2007;12(36). pii=3260. Available from: http://www.eurosurveillance.org/ ViewArticle.aspx?Articleld $=3260$

67. Meroc E, Faes C, Herr C, Staubach C, Verheyden B, Vanbinst $\mathrm{T}$, et al. Establishing the spread of bluetongue virus at the end of the 2006 epidemic in Belgium. Vet Microbiol. 2008;131(1-2):133-44.

68. Moretti G. [African trypanosomiasis detected in France. Difficulties of diagnosis]. Presse Med. 1969;77(41):1404. [French].

69. Tatem AJ, Hay SI, Rogers DJ. Global traffic and disease vector dispersal. Proc Natl Acad Sci U S A. 2006;103(16):6242-7. 